\title{
THE POLICY OF "RECONSTRUCTION" AND ITS PECULIARITIES IN THE SOCIO-POLITICAL LIFE OF UZBEKISTAN
}

\author{
Khurshid Egamberdievich Khodjamberdiev \\ Senior teacher at the department "Theory of civil society" of Andizhan State University, Andizhan, \\ Uzbekistan
}

Article DOI: https://doi.org/10.36713/epra2270

\begin{abstract}
This article illuminated that the early 1980s, the social and political development of the Soviet Union began to show signs of decline. Therefore, a period of rapid decline in economic and social life began and also extensive development of the economy has resulted in more costs, and this has already begun to manifest itself in the political and social spheres were opened by the helping scientific literatures and archive documents as well.
\end{abstract}

KEY WORDS: policy, Uzbekistan, culture, ecology, education, industry, reconstruction, import, export.

\section{INTRODUCTION}

By the early 1980s, the social and political development of the Soviet Union began to show signs of decline. A period of rapid decline in economic and social life began. Extensive development of the economy has caused more costs, and this has already begun to manifest itself in political and social spheres.

Since Uzbekistan was a part of the USSR during the reconstruction period, there were realities inherent in the socio-political situation in other Soviet republics. By the mid-1980s, all the ministries and departments of culture, health, education, social services and all the plants and factories in Uzbekistan were headed by the Union Ministries. The Communist Party of Uzbekistan, the main political institution that governs the state of Uzbekistan, was a political organization within the regional jurisdiction of the RSFSR. Decisions of the Central Committee of the Central Committee of the Communist Party of Uzbekistan were considered in the plenum of the Central Committee of the Communist Party of Uzbekistan, and its decisions were considered in the plenums of regional, district and city party organizations. Political, economic, social and other spheres were directly headed by district and city party organizations. The prospective development indicators of all five republics, including Uzbekistan, were approved by the State Planning Committee of the USSR, and no state organization could change it in Uzbekistan. The republic had to fulfill its annual and five-year plan, whatever its potential or capabilities. That is why in all of the Union republics, the implementation of plans was at the height of [1], [92].

\section{METHODS}

The new colonial plan for the deployment of productive forces was foreseen for the economy of the republic to be unilaterally oriented only on raw materials. As a result, industries in the country related to primary processing of raw materials have more developed. The share of finished goods in the industry was only $25 \%$ of the total output, and consumer goods production was only $40 \%$ of the average union level. Errors in the economy and specialization of production have led to an increase in the resource potential and environmental disadvantages of Uzbekistan, worsening of material and financial conditions [2], [625], [626]. 


\section{EPRA International Journal of Research and Development (IJRD) \\ Volume: 5 | Issue: 2 | February 2020 \\ - Peer Reviewed Journal}

In the $1980 \mathrm{~s}$, the social orientation of the economy was ineffective, and the neglect of the social interests and needs of the people became one of the characteristic features of this period. The Great Red Empire failed to create the country's ability to raise real incomes, improve living conditions, regular food, health care and health care, and the social policy in this area was driven not by the people's interests but by the will of the conservative party. Whereas during this period, the US spent $\$ 3,386$ per pupil per year, \$ 258 in the USSR, spending \$2,885 in England, and \$ 3,33 per child in the US $\$ 533$. The USSR was the average of the Union, and the situation in Uzbekistan was lower than the average.

By the mid-1980s, Uzbekistan was ranked one of the last in the union in terms of socio-economic indicators. In particular, the gross national income throughout the country was twice lower than the Union average. Also, the food and social security of the population of the Republic declined. At the same time, Uzbekistan was forced to import food, agricultural machinery and even textile products. As a result, imports more than doubled exports, and estimates that milk, meat, eggs and fish and other key consumer goods accounted for more than half of the average EU per capita. The black market accounted for about $20 \%$ of Uzbekistan's total trade turnover as a result of the Center's failure to meet its basic consumer needs. Whereas the black market traded at a much higher price. This was one of the factors contributing to the decline in living standards [4], [31].

The center was mainly exporting raw materials from Uzbekistan. Equipment from the Center and other republics was supplied from Uzbekistan. This led to the growth of industry in the European Union, and forced the Uzbek industry to be in a state of recession.

\section{RESULTS AND DISCUSSIONS}

The adaptation of almost all cultivated fields to cotton fields has grown at an unprecedented rate. Only about $45-50 \%$ of the nitrogen fertilizers applied to cotton in the past have a beneficial effect, while the remaining 50-55\% have been washed away from the soil, blown into the air and polluted the environment [5]. With the use of many toxic fertilizers, the pollution of the air, water, food, fruits and melons has threatened human health and created new diseases. During the medical examination of the population living in the Aral Sea region, $54 \%$ to $72 \%$ of the total population was identified. Of these, 50-63\% were children [6], [51] the infant mortality rate increased significantly and the Republic rose to one of the highest rates in the world. In Uzbekistan, the under-five mortality rate is 37.7 per 1,000, and 52 in Karakalpakstan. The prevalence of handicapped children is $35-36 \%$ of the total number of sick children in Uzbekistan [7], [170].

Child and maternal mortality in cottongrowing districts have more than tripled in non-cotton areas. Oncological diseases were ten times more than the Union average [8], [52]. The number of suicides among women has increased as a result of hard life. The standard of living of our people has fallen several times lower than those of third world countries. The unpredictable and inappropriate use of water has led to the Aral catastrophe [9].

During this time, the same old policy continued to be more cultured and more thoroughly masked. In order to meet the ever-growing demand for raw materials in the European Union, Uzbekistan has also used the latest cotton production opportunities. As a result, the environmental situation worsened and labor became even harder. The standard of living of the population has become more difficult, and socioeconomic problems have become more acute.

The Center's economic development programs, party and government decisions did not take into account the interests of allied republics. Even during the reconstruction period, the center was able to address the causes of the economic crisis in the Union to the allied republics and to ensure the consumption of consumer goods. In the republics, which have been accustomed to the distribution of the center's extensive consumer goods for 70 years, disruptions in the provision of basic foodstuffs have begun. Reform and democratization of the political system and the participation of the general public in political and historical processes have resulted in unexpected consequences for the Center [10].

Partial democratic freedoms, openness, and guarantees of self-government of the people during the "reconstruction" failed to radically improve the welfare of the population. Because the old methods of management, production and ownership were abolished and the new ones were broken, economic ties between the union republics were broken, the center's intention to reign again, the internal political struggles, the power struggle between the RSFSR and the union and its structures. aggravated the financial situation of the people. The shortage of consumer goods and foodstuffs has exacerbated, and prices have steadily increased.

During these difficult times, attempts by a group of members of the Central Authority - the Political Bureau of the Communist Party to attempt a coup on 19-21 August 1991 - showed that Uzbekistan could no longer be the vassal of the center. Some actions of the political forces that won the center, attempts to occupy the union structures without any agreement with other republics, the participation of 


\section{EPRA International Journal of Research and Development (IJRD) \\ Volume: 5 | Issue: 2 | February 2020 \\ - Peer Reviewed Journal}

some of the top leadership of the Communist Party in the coup, the suspension of the activities of the Communist Party of the republic have called into question the development of our republic. In addition, there was still a central position in the center that sought to maintain the old imperial relations with the republics.

At the same time, economic ties with the allied republics were severed, and economic ties formed over half a century were disrupted. The value of the ruble issued by the center has dwindled, and economic ties have sought to obtain economic resources through the exchange of natural goods, and have resisted the expropriation of their wealth. As a result, since 1991 all republics, including Uzbekistan, have begun to disobey the center and pursue their own national interests. The republic's "parade of sovereignty" has begun.

There were also peculiarities of Uzbekistan's dependence on the center. The economy of the republic during the Soviet period was viewed as part of a unified centralized economic system. The interests of Uzbekistan were rarely taken into account in the administration of the Center and its economic policy. The republic was developed as a favorable market for the finished product, supplying cheap raw materials and strategic mineral resources to the former Soviet Union. This condition required the republic to become an agroeconomic entity.

Any attempt to alleviate the economic and environmental tension in Uzbekistan, national selfconsciousness, the Center's efforts to break down the pressure, the most appropriate and specific paths to the republic were considered "localism", "nationalism" and severely eradicated, even centralized. funding and resource constraints [11], [626].

Many industrial enterprises based in Uzbekistan were directly subordinated to the center and were not managed by the government. The country manages more economic activities, such as mining and primary processing of raw materials, semi-finished products, defense products, but all products manufactured in this area are exported. Most industrial enterprises produced their own goods not for the domestic market but for the center's exportation. Nobody knew about the statistics. In other words, the center is responsible for the income of national products [12].

The main purpose of the Union leadership was to create a unified national economic system. As part of this policy, industrial enterprises in Uzbekistan were established in terms of the transportation of natural resources from the Republic. The range of industrial products is limited, mainly for the production of construction materials, light industry goods and cotton fiber. During the period 1980-1990, cotton, light and textile enterprises accounted for $57.3 \%$ of total industrial production in Uzbekistan. In Andijan, Namangan, Ferghana, Tashkent, Samarkand, Khorezm and Bukhara regions, the number of unemployed increased due to the relatively small number of industrial enterprises relative to population growth [13].

Social life in Uzbekistan depended on cotton production, on the one hand, and industrial development on the other. Of the 1,267 large industrial enterprises operating in Uzbekistan in 1988, only 320 (ie 25.3 percent) were fully self-financing. These enterprises accounted for $55.7 \%$ of the total industrial output in the country. The rest of the enterprises (947, or $74.7 \%$ ) delivered the remaining $44.3 \%$, which is $0.7 \%$ less than the previous year. In $1988,39.2 \%$ of the country's output was produced on the state order. The state orders for agricultural machine-building enterprises accounted for more than $90 \%$ of the total production output and $85 \%$ in the machine-building industry [14], [428].

In the late $1980 \mathrm{~s}$, the country was in crisis as a result of population growth, ie the integration of demographic and economic problems. The standard of living of the population was steadily declining. By 1988, income of the Central Asian population, in particular Tajikistan's 59\%, Uzbekistan 45\%, and Kyrgyzstan and Turkmenistan $37 \%$, was below the subsistence minimum. Most surprisingly, the Union did not have a measure of poverty in the population [15], [4] by 1990 , about $70 \%$ of the country's total income had fallen below the subsistence minimum. Also, unemployment has been increasing year by year [16], [26].

The report of the German Institute for SocioEconomic Development in Central Asia evaluates the situation as follows: "By 1990, Central Asia was already in an unbearable social situation - widespread poverty and unemployment, housing shortages, education. As a result of the reforms of the early 1990s, we can say that the communist ideology was completely alien to our people and could not be reflected in the totalitarian society for more than 70 years. Because Marxism-Leninism, as an idea or ideology, was a complete doctrine of the national heritage, traditions and historical memory of our people. Communist doctrines are completely alien to the mentality of the Uzbek people. There were no social, political, economic or ideological conditions in Uzbekistan for the proletarian revolution and dictatorship [17].

The politics of pride, poverty, equality of all dependence on the power of the poor, the use of pressure, fear, and use of force among the people are in 


\section{EPRA International Journal of Research and Development (IJRD) \\ Volume: 5 | Issue: 2 | February 2020 \\ - Peer Reviewed Journal}

crisis. By dividing society into polarized classes based on the criteria of wealth and poverty, the idea, ideology and worldview of forcibly mobilizing millions of people to build a fantastic communist society through artificial ways and means, such as creating artificial enemy images, has never really penetrated the nature of the Uzbek people. Although the people obeyed the party, the authorities and its bodies only as factors of organization and way of life, they were deeply aware of the socio-political and ideological goals of this system, both in their own life and in their own thinking processes.

\section{CONCLUSION}

In sum, the consequences of the reconstruction were as follows:

- The totalitarian regime in the USSR was abolished, the hegemony of KPSS in political life was eliminated;

- The USSR collapsed. On its territory independent states were established;

- The planned economic system is abolished, the conditions for market relations formation have been created;

- Pluralism in social and political life has been formed, a multi-party system has emerged;

- The Cold War policy has been abolished, and changes have been made in the deployment of world powers; abolished

- The "socialist system of the world" was

All in all, in the late 1980s, the Republic inherited from the former Soviet Union the ideological monarchy, economic crises, people's distrust of the state and the system, and the disintegration of the nation. In such a difficult and dangerous environment, the goals of development, such as solving the existing problems and mobilizing the people for national independence, were the priorities of the development agenda. In this difficult period of history, Islam Karimov's election as president, his early work, and his early reforms to change social and economic life have given the nation a sense of hope for the future.

\section{REFERENCES}

1. F.Razzakov.The case that blew up the USSR. Moscow: Algorithm, 2012. - p.92

2. The modern history of Uzbekistan. The second book. Uzbekistan during the Soviet colonial era. Scientific editor M. Jurayev. - T: Shark, 2000. - p. 625-626.

3. Ferghana Regional State Archives, Fund 408, List 5, 243 Works, Pages 13.

4. John Staples. Soviet Use of Corruption Purges as a Control Mechanism: The Uzbekistan Casel/Past Imperfect, Vol. 2, 1993. - P. 31.
5. https://ziyouz.uz/matbuot/qayta-qurish-davrimatbuoti/abduqodir-ergashev-oguning-bahosiqancha-1990/

6. National Archive of Uzbekistan (NAUz),R.2454fund, list-6, collected volume-7076,-p.51.

7. NAUz, R.837-fund, list-41, collected volume -7991, p.170.

8. NAUz, R.2454-fund, list-6, collected volume-7076, p.52.

9. E.Yusupov, S.Ziyadullaev. Aralu live! Aral - to develop // Pravda Vostoka, July 7, 1987.

10. History of Uzbekistan (1917-1991). The second book. 1939-1991. - Tashkent: Uzbekistan, 2019. - p. 163.

11. The modern history of Uzbekistan. The second book. Uzbekistan during the Soviet colonial era. Scientific editor M. Jurayev. - T: Shark, 2000. - p.626.

12. “Soviet Uzbekistan”, March 19, 1989.

13. Urbanization in Central Asia: Challenges, Problems and Prospects. I Analytical report 2013/03. Center for Economic Research. Tashkent, 2013. - p. 19-20.

14. History of Uzbekistan (1917-1991). The second book. 1939-1991. - Tashkent: Uzbekistan, 2019.p. 428 .

15. K.Muler. Poverty and Social Policy in Central Asian Transition Economies. / Reports and expert opinions 6/2003. Bonn: German Institute for Cooperation and Development, 2003. - p.4.

16. Textbook for the Study of the First President of the Republic of Uzbekistan Islam Karimov "Uzbekistan on the threshold of Independence" / Responsible Creative Group: A.Sh. Bekmurodov et al. - T: Ukituvchi, 2011. - p. 26.

17. K.Muler. Poverty and Social Policy in Central Asian Transition Economies. / Reports and expert opinions 6/2003. Bonn: German Institute for Cooperation and Development, 2003. - p.58. 